\title{
An Architectural Review of Privacy Value in Traditional Indonesian Housings: Framework of Locality-Based on Islamic Architecture Design
}

\author{
Muhammad Ismail Hasan ${ }^{1,}$ Bintang Noor Prabowo², Hazrina Haja Bava Mohidin³,4* \\ ${ }^{1}$ Vocational School, Universitas Diponegoro 50275 Semarang, Indonesia \\ ${ }^{2}$ Department of Civil and Environmental Engineering, Norwegian University of Science and \\ Technology (NTNU), Tronheim, 7034 Norway. \\ ${ }^{3}$ Department of Architecture, Faculty of Built Environment, University if Malaya, 50603 Kuala \\ Lumpur, Malaysia \\ ${ }^{4}$ Centre for Sustainable Urban Planning \& Real Estate (SUPRE), Faculty of Built Environment, \\ University of Malaya 50603 Kuala Lumpur, Malaysia \\ 1*hazrinahaja@um.edu.my
}

This study aims to provide an understanding of the locality-based privacy of traditional Indonesian houses, which is in line with Islamic architecture values. This study reviews scientific papers about traditional Indonesian houses and summarizes the privacy establishment of each house. The result of the summary found that privacy in traditional Indonesian houses consists of physical and non-physical. Physical privacy comprises separator or divider; height adjustment for building elements; build layers of rooms as transitional space; clear division of zoning; selected wall material; and distinction entrance. In comparison, non-physical privacy involves spatial agreement and gender spatial that requires agreement space between men and women. This study is expectedly fruitful for the development of Islamic-based concept residence in the Indonesian real estate realm.

Keywords: privacy, locality, traditional houses, Indonesia 


\section{INTRODUCTION}

A house represents various of its dwellers and local geographic conditions. In terms of dwellers, beliefs and culture possess significant roles that establish a house itself, either layout, material, or zoning (Zahrani \& Tabaeian, 2016). Islam as a belief contributes a substantial influence for its believers in dwelling through Muslim houses embodied in Islamic Architecture (Othman et al., 2015). Islamic architecture is also developing rapidly in various countries, including Indonesia, a country with the largest Muslim population worldwide. Early Islamic Architecture in Indonesia grew harmoniously with the previous culture and acculturated, and subsequently, it was accepted by non-Muslim people (Idham, 2021). The spirit of harmonization and acculturation between Islamic Architecture and previous local culture aligns with the statement for the sociocultural strategy to emerge a sense of community and identity (Wiryomartono, 2014). Afterward, it will develop sustainability that is physical and natural and considers social tuning (Idham, 2018).

Islamic architecture is embodied from Islamic values sourced from Quran, sunnah, and fiqih; thus, it is established as a framework for this architectural style and responds to Muslim dwellers' needs to practice their faith (Omer, 2010) (Mortada, 2003). Islamic architecture is inseparable from privacy which is the substantial value of this architecture. Studies explained that privacy is essentially required in Islamic architecture and established in Muslim houses as a need (Omer, 2010) and provides private and safe space for house members (Othman, 2016).
The key to privacy announced is even broader explain in the realm of the built environment (Mortada, 2003). Those preliminary studies considering the importance of privacy in Islamic Architecture and the focus of this study outright.

However, privacy and the designated private area must be well-reviewed to establish a haphazard understanding. Treatments for privacy do not simply present as a closed area; somewhile it develops as a balance between two areas, more and less open, the other is more and less closed (Boettger, 2014). This study also responses to an issue stated by Idham (2018) that the recent development of Islamic Architecture understanding was beginning from a conservative understanding of sharia and ended up "Islamic purification movement," which importing the architecture (Idham, 2021). Whereas distinctive spatial spaces in local Indonesian houses are generated by culture and daily practices, as a consequence, it requires a comprehensive investigation. Hence this study aims to generate distinctive privacy in Indonesia.

\section{METHODS}

Scientific publications regarding traditional Indonesian houses were collected to generate the locality in privacy value. Twenty-one publications consist of two books, nine journals, and ten proceedings issued from 2014 to 2021 were selected for synthesizing. These scientific publications discuss their case studies about traditional Indonesian houses from various areas around Indonesia. An outline of 21 publications is presented in Table 1.

Table 1. Outline of Literature Review

\begin{tabular}{|l|l|l|l|l|l|}
\hline \multicolumn{1}{|c|}{ Author } & $\begin{array}{c}\text { Publication } \\
\text { type }\end{array}$ & $\begin{array}{c}\text { Data } \\
\text { location in } \\
\text { Indonesia }\end{array}$ & $\begin{array}{c}\text { Findings in privacy } \\
\text { establishment }\end{array}$ & $\begin{array}{c}\text { Physical } \\
\text { (p) / } \\
\text { non- } \\
\text { physical } \\
\text { (np) }\end{array}$ & \multicolumn{1}{|c|}{ Keyword } \\
\hline $\begin{array}{l}\text { (Wiryomartono, } \\
\text { 2014) }\end{array}$ & Book & Various & $\begin{array}{l}\text { Wall as a separator to } \\
\text { allow hospitality }\end{array}$ & $\mathrm{p}$ & Separator \\
\hline $\begin{array}{l}\text { (Suprapti, } \\
\text { 2014) }\end{array}$ & Journal & $\begin{array}{l}\text { Kudus, } \\
\text { Central } \\
\text { Java }\end{array}$ & $\begin{array}{l}\text { Treatment on the } \\
\text { openings and designated } \\
\text { house plan }\end{array}$ & $\mathrm{p}$ & $\begin{array}{l}\text { Height } \\
\text { adjustment }\end{array}$ \\
\hline $\begin{array}{l}\text { (Mustafa et al., } \\
\text { 2016) }\end{array}$ & Proceeding & $\begin{array}{l}\text { Makassar, } \\
\text { Sulawesi }\end{array}$ & $\begin{array}{l}\text { Transitional space } \\
\text { between public and } \\
\text { private space }\end{array}$ & $\mathrm{p}$ & $\begin{array}{l}\text { Transitional } \\
\text { space }\end{array}$ \\
\hline
\end{tabular}




\begin{tabular}{|c|c|c|c|c|c|}
\hline $\begin{array}{l}\text { (Darmayanti, } \\
\text { 2016) }\end{array}$ & Proceeding & West Java & $\begin{array}{l}\text { Clear division of gender- } \\
\text { based space }\end{array}$ & $\mathrm{p}$ & Zoning \\
\hline $\begin{array}{l}\text { (Suprapti et al., } \\
\text { 2017) }\end{array}$ & Journal & $\begin{array}{l}\text { Semarang, } \\
\text { Central } \\
\text { Java }\end{array}$ & $\begin{array}{l}\text { Women space to protect } \\
\text { their activities }\end{array}$ & $\mathrm{p}, \mathrm{np}$ & $\begin{array}{l}\text { Zoning, } \\
\text { gender } \\
\text { spatial }\end{array}$ \\
\hline $\begin{array}{l}\text { (Suharto et al., } \\
\text { 2018) }\end{array}$ & Proceeding & $\begin{array}{l}\text { Makassar, } \\
\text { Sulawesi }\end{array}$ & $\begin{array}{l}\text { Private rooms are located } \\
\text { in a separate area }\end{array}$ & $\mathrm{p}$ & Zoning \\
\hline $\begin{array}{l}\text { (Raka \& Runa, } \\
\text { 2018) }\end{array}$ & Proceeding & Bali & $\begin{array}{l}\text { Privacy achieved by } \\
\text { thickening the walls }\end{array}$ & $\mathrm{p}$ & Material \\
\hline (Ju et al., 2018) & Journal & Yogyakarta & $\begin{array}{l}\text { Higher floor peel and } \\
\text { transitional space } \\
\text { establish a clear division } \\
\text { of the private area }\end{array}$ & $\mathrm{p}$ & $\begin{array}{l}\text { Height } \\
\text { adjustment, } \\
\text { zoning, } \\
\text { Transitional } \\
\text { space }\end{array}$ \\
\hline $\begin{array}{l}\text { (D. P. Sari \& } \\
\text { Chiou, 2019) }\end{array}$ & Proceeding & $\begin{array}{l}\text { Central } \\
\text { Java }\end{array}$ & $\begin{array}{l}\text { Designated guest room } \\
\text { for hospitality and } \\
\text { gathering, zoning to } \\
\text { locate public and private } \\
\text { spaces }\end{array}$ & $\mathrm{p}$ & Zoning \\
\hline (Santosa, 2019) & Book & Yogyakarta & $\begin{array}{l}\text { Zoning and gender } \\
\text { segregation }\end{array}$ & $\mathrm{p}, \mathrm{np}$ & $\begin{array}{l}\text { Zoning, } \\
\text { gender } \\
\text { spatial }\end{array}$ \\
\hline $\begin{array}{l}\text { (Fanggidae et } \\
\text { al., 2019) }\end{array}$ & Journal & Kupang & $\begin{array}{l}\text { Distinction area based on } \\
\text { gender, private space } \\
\text { convertible to public } \\
\text { space for hospitality }\end{array}$ & $\mathrm{np}$ & $\begin{array}{l}\text { Spatial } \\
\text { agreement }\end{array}$ \\
\hline $\begin{array}{l}\text { (Elfira \& } \\
\text { Wibawarta, } \\
\text { 2019) }\end{array}$ & Journal & $\begin{array}{l}\text { West } \\
\text { Sumatra }\end{array}$ & $\begin{array}{l}\text { Prioritizing more space } \\
\text { for gathering areas rather } \\
\text { than private space. } \\
\text { Private space for bedroom }\end{array}$ & $\mathrm{p}$ & Zoning \\
\hline (Anwar, 2019) & Proceeding & $\begin{array}{l}\text { Palembang, } \\
\text { South } \\
\text { Sumatra }\end{array}$ & $\begin{array}{l}\text { Higher level of the floor } \\
\text { than public space, private } \\
\text { rooms separated by a } \\
\text { divider }\end{array}$ & $\mathrm{p}$ & $\begin{array}{l}\text { Height } \\
\text { adjustment }\end{array}$ \\
\hline $\begin{array}{l}\text { (I. kartika Sari } \\
\text { et al., 2019) }\end{array}$ & Journal & $\begin{array}{l}\text { West } \\
\text { Borneo }\end{array}$ & $\begin{array}{l}\text { Adjusting the height of } \\
\text { building and openings } \\
\text { and indirect openings to } \\
\text { get privacy visually }\end{array}$ & $\mathrm{p}$ & $\begin{array}{l}\text { Height } \\
\text { adjustment }\end{array}$ \\
\hline $\begin{array}{l}\text { (Naing \& Hadi, } \\
\text { 2020) }\end{array}$ & Journal & $\begin{array}{l}\text { Bone, } \\
\text { Sulawesi }\end{array}$ & $\begin{array}{l}\text { Segregation space } \\
\text { between family spaces } \\
\text { and living room }\end{array}$ & $\mathrm{p}$ & Zoning \\
\hline $\begin{array}{l}\text { (Napitupulu et } \\
\text { al., 2020) }\end{array}$ & Proceeding & $\begin{array}{l}\text { North } \\
\text { Sumatra }\end{array}$ & $\begin{array}{l}\text { Zoning, gender } \\
\text { segregation, and a guest } \\
\text { room is provided }\end{array}$ & $\mathrm{p}$ & Zoning \\
\hline $\begin{array}{l}\text { (Samra \& } \\
\text { Imbardi, 2020) }\end{array}$ & Proceeding & $\begin{array}{l}\text { Riau, } \\
\text { Sumatra }\end{array}$ & $\begin{array}{l}\text { No divider in Malay } \\
\text { house, but married } \\
\text { daughter's room equipped } \\
\text { by divider }\end{array}$ & $\mathrm{p}$ & Separator \\
\hline (Siahaan, 2020) & Proceeding & $\begin{array}{l}\text { Nias, West } \\
\text { Sumatra }\end{array}$ & $\begin{array}{l}\text { Separated doors to access } \\
\text { public \& private spaces }\end{array}$ & $\mathrm{p}$ & Entrance \\
\hline $\begin{array}{l}\text { (Hastorahmanto } \\
\text { et al., 2020) }\end{array}$ & Journal & Yogyakarta & $\begin{array}{l}\text { Two layers of the guest } \\
\text { room, outer guest room }\end{array}$ & $\mathrm{p}$ & Zoning \\
\hline
\end{tabular}




\begin{tabular}{|l|l|l|l|l|l|}
\hline & & & $\begin{array}{l}\text { for public space, inner } \\
\text { guest room for kinship } \\
\text { guest }\end{array}$ & & \\
\hline (Idham, 2021) & Journal & $\begin{array}{l}\text { Central } \\
\text { Java and } \\
\text { Yogyakarta }\end{array}$ & $\begin{array}{l}\text { Zoning to gather and } \\
\text { maintain women \& } \\
\text { family privacy }\end{array}$ & $\mathrm{p}, \mathrm{np}$ & $\begin{array}{l}\text { Hospitality, } \\
\text { gender } \\
\text { spatial, } \\
\text { space } \\
\text { agreement }\end{array}$ \\
\hline $\begin{array}{l}\text { (Izziah et al., } \\
\text { 2021) }\end{array}$ & Proceeding & $\begin{array}{l}\text { Aceh, } \\
\text { Sumatra }\end{array}$ & $\begin{array}{l}\text { Zoning and gender } \\
\text { segregation }\end{array}$ & $\mathrm{p}, \mathrm{np}$ & $\begin{array}{l}\text { Zoning, } \\
\text { gender } \\
\text { spatial }\end{array}$ \\
\hline
\end{tabular}

\section{RESULT AND DISCUSSION}

The establishment of privacy in several traditional Indonesian housings are various and consist of physical and non-physical. The previous outline shows that establishment of privacy physically formed by separator or divider; height adjustment for building elements; build layers of rooms as transitional space; clear division of zoning; selected wall material; and distinction entrance. Physical forms of privacy dominate the initial studies collected for this research. Afterward, non-physical privacy is formed by spatial agreement and gender spatial that requires agreement space between men and women. Notably, physical privacy establishment is tangible and determining the personal character. The elimination of these physical factors will vanish privacy. At the same time, nonphysical privacy is established by respectful agreement between house members and guests.

\subsection{Physical Form of Privacy}

\section{Separator/ Divider}

In his book about traditional settlements in Indonesia, Wiryomartono explains that wall ables define private and provide hospitality space properly. Instead of receiving guests in front of the house to hide the privacy, the wall allows house owners to receive guests inside their house politely and in the cage of hospitality (Wiryomartono, 2014). The separator function to maximize hospitality is in line with the characteristic of Malay houses in Riau. Malay houses in Riau are equipped with no separator but a married daughter's room (Samra \& Imbardi, 2020). The presence of a separator stipulates a clear division of zoning outright, but study about Malay houses in Riau proof that divider will only be built if it is indispensable, such as providing private space for the spouse.

\section{Height Adjustment}

Existing studies provide various height adjustments on building elements is intended to increase the privacy level. Occasionally traditional houses in Indonesia are unique due to the organization of rooms defined by higher floor peel. Indigenous Joglo houses, which spread around Central Java and Yogyakarta, are equipped with this feature to define the privacy level of a domestic spatial area. Gandhok, a family's private space in Joglo found higher floor peel than Pringgitan and Pendhapa as space to receive guests (Ju et al., 2018). Limas house of Southern Sumatra also treats the level of domestic spatial with floor peel. Bengkalis Atas as a sitting space for distinguished guests located $15-40 \mathrm{~cm}$ higher than other floors, and the family's private areas follow right behind the Bengkalis Atas with the same height of floor peel (Anwar, 2019).

Increasing the height of house elements also occurs in windows and the whole floor of the house to create privacy in visual. Native houses in Kudus Kulon treat the windows higher than usual and enclose an additional screen in front of the door to obstruct visual from outside (Suprapti, 2014). Malay houses also engendered height level treatment for privacy in West Borneo. The house is built on 1-1,8 meter stilts and avoids locating windows and doors facing neighbors' openings to maintain visual privacy (I. kartika Sari et al., 2019).

The adjustment of house elements' height acquires an increased level of privacy. Floor peel explains that private spatial is higher among other domestic spatial. While privacy is visually achievable with treatment to openings such as: built house on stilts, high mount of windows, enclosed door layer, and avoid mounting openings facing neighbour's openings.

\section{Transitional space}


Except for higher floor peel, traditional houses of Yogyakarta are also equipped with transitional space from outside to inside houses, namely Emperan and Kuncungan (Ju et al., 2018). Recently, Indonesian houses employ Emper as a guest room due to limitation space of the house. Transitional space in Makassar traditional houses is called Bale-bale and has a double function; screen guests before receiving and interact with neighbors (Mustafa et al., 2016). Hence, those studies indirectly explain another function of transitional space apart from "waitingspace before received", that is hospitality function. Aminuddin (2009) also explained the need of social transitional space and how it is impostant for the social hierachy.

\section{Zoning}

Zoning is the primary contributor form of privacy in traditional Indonesian houses. Clear division of zoning in the house leads privacy to a-must-have space in domestic spatial. Sundanese traditional houses of Kampung Naga are an example of an obvious distinction between spaces which accessible and inaccessible for guests (Darmayanti, 2016).

Practices of zoning through the distribution of rooms toward several areas also determine from house area for receiving guests, a central area for private family space, and rear house area for service purpose (Suharto et al., 2018) (D. P. Sari \& Chiou, 2019) (Naing \& Hadi, 2020). Distribution of house spaces brings the characteristic of traditional Indonesian houses to provide guest room for maintaining hospitality or organize gathering (Elfira \& Wibawarta, 2019) (Napitupulu et al., 2020) (Hastorahmanto et al., 2020) (Izziah et al., 2021). Apart from providing hospitality and gathering space, studies elaborate that the gender spatial as the fundamental of clear division of zoning in Indonesia traditional houses, and gives particular concern to women space outright (Darmayanti, 2016) (Suprapti et al., 2017) (Santosa, 2019) (Elfira \& Wibawarta, 2019) (Napitupulu et al., 2020) (Izziah et al., 2021).

\section{Wall Material}

The matter of wall material based on table 1 above only happened in Bali. The case study of ancient traditional Balinese houses underwent renovation on the wall to increase privacy due to behavioural changes (Raka \& Runa, 2018). Changes in soundproof material often occur to increase acoustic privacy from unlawful listening (Babangida \& Katsina, 2018).
Another practice of privacy physically is the distinction entrance house. Omo Hada, traditional house of Nias adjusting door entrance based on the characteristic of the spatial. One larger door to public space and one smaller door towards private space (Siahaan, 2020). Multi entrance in a house is also found in authentic traditional houses of Kauman Semarang (Suprapti et al., 2018). The house is usually equipped with Lengkong, a private alley to access the service area from outside then link to private space. Hence, to reach service and the private area should not thru public space or guest room.

\subsection{Non-Physical Form of Privacy}

\section{Spatial Agreement}

Everyday culture based on spatial practices establishes privacy in traditional Indonesian houses. Activities involved in everyday culture determine men's activity and women's activity. Distinctive masculine activity such as farming and other outdoor activities locates men's territory near farming tools, whereas feminine activity such as cooking and cleaning the house locates women's territory near kitchen utensils (Idham, 2021). Those practices establish a spatial agreement which inseparable from gender activity. The spatial agreement is substantially embodied in a room with a divider or even without any divider.

Spatial agreement in houses determines rear houses such as kitchen and service areas as a feminine activity, thus stipulated as women's area (Idham, 2021) (Izziah et al., 2021). It exemplifies spatial agreement with the divider. In contrast, ancient traditional houses in Kupang provide an example of a space agreement established without dividers. Everyday local culture agrees to men's territory located in the left house, while women territory in the right, and between them built no divider, although in women territory has a divider at rear (Fanggidae et al., 2019). Other area such as the outdoor spaces will be the inbetween of semi-private to private transition (Zulkifli A, Aminuddin Asrul 2020). Whenyuan (2020) also reiterated the significant of spatial integral for outdoor to indoor and vice versa.

\section{DISCUSSION}

\section{Distinction Entrance}




\section{Linkages of Privacy in Indonesia Traditional Houses and Privacy in Islamic Architecture}

Privacy in Islamic houses is highly respected, and the core value of privacy in Islamic architecture is to provide a safe shelter for the family from outside (Omer, 2010)(Othman, 2016). Well-maintained privacy will escalate the intimacy and comfort for dwellers (Kameli et al., 2016) and promote ethical behavior for children toward their parents (Babangida \& Katsina, 2018). Even though publications provided in the literature review outline are not whole taken from Indonesian Islamic culture, the concept of privacy is urgent to be studied to establish the value of a locality in privacy.

The use of separator/ divider, height adjustment for building elements, clear zoning division, and space agreement are intended to protect women (mother, wife, and daughters) from unlawful sight. At the same time, the selected material of the wall is intended to diminish acoustic privacy breaching. As The Qur'an warns those who breach someone's privacy:

"Do you who believe! Avoid suspicion as much (as possible): for suspicion in some cases is a sin: and spy not on each other, nor speak ill of each other behind their backs. Would any of you like to eat the flesh of his dead brother? Nay, you would abhor it...But fear Allah: for Allah is Oft-Returning Most Merciful" (The Quran, Al Hujurat: 12)

Thus, building layers of rooms as transitional space and distinction entrance is intended as a screen for the house owners to their guest.

"O believers! Do not enter any house other than your own until you have asked for permission and greeted its occupants. This is best for you, so perhaps you will be mindful." (The Quran, An-Nur: 27)

\section{CONCLUSION}

The majority of privacy values from selected traditional houses are intended to protect women dwellers and constitute ethics to respect the house owner. Although traditional houses of Indonesia prevail in strict privacy, the fundamental characteristic of Indonesian in hospitality is well preserved. In other words, maintaining privacy is intended to receiving and treat the guest decently without diminishing the secure feel of dwellers.
The presence of guest rooms in traditional houses of Indonesia should be a consideration to not abolish in current housing design. Hence the hospitality characteristic of Indonesian will be well maintained. Furthermore, physical and non-physical privacy values embodied in traditional Indonesian houses also in line with the Islamic architecture concept. This study is expectedly fruitful for the development of Islamic-based concept residence in the Indonesia real estate realm.

\section{ACKNOWLEDGMENT}

A grateful is dedicated to Universitas Diponegoro to provide support in financial through BEASISWA UNDIP to conduct $\mathrm{Ph}$.D. research at the University of Malaya.

\section{REFERENCES}

1. Aminuddin Asrul, G.K. Yong. 2009. Study on Lowcost High Rise Urban Housing in Kuala Lumpur Impact on Communities and Social Spaces. International Journal for Housing Science and Its Application. Vol.33 No.2 (SCOPUS-Indexed).

2. Anwar, W. F. F. (2019). The Building Performance of Limas House; Dealing with Current Context. Journal of Physics: Conference Series. https://doi.org/10.1088/17426596/1198/8/082029

3. Babangida, H., \& Katsina, H. S. (2018). INTEGRATING ISLAMIC DESIGN PRINCIPLES FOR ACHIEVING FAMILY PRIVACY IN RESIDENTIAL ARCHITECTURE. Journal of Islamic Architecture, $\quad 5(1), \quad 9$. https://doi.org/10.18860/jia.v5i1.4407

4. Boettger, T. (2014). Threshold Spaces. In Threshold Spaces. Birkhäuser Verlag GmbH,. https://doi.org/10.1515/9783038214007

5. Darmayanti, T. E. (2016). The Ancestral Heritage: Sundanese Traditional Houses Of Kampung Naga, West Java, Indonesia. In S. N. B. Kamaruzzaman, A. S. B. Ali, N. F. B. Azmi, \& S. J. L. Chua (Eds.), MATEC Web of Conferences (Vol. 66, p. 00108). EDP Sciences. https://doi.org/10.1051/matecconf/201666001 08

6. Elfira, M., \& Wibawarta, B. (2019). "More like living with it than in it": The modified functions ff Minangkabau Rumah Gadang of 
West Sumatra, Indonesia. Global Journal AlThaqafah, 9(1), 71-78.

7. Fanggidae, L. W., Yoyok Wahyu Subroto, T., $\&$ Nareswari, A. (2019). The persistence of the traditional house's spatial system in the migrant street vendor's stalls. International Journal of Scientific and Technology Research, 8(09), 586-594.

8. Hastorahmanto, P. S., Soetomo, S., \& Sardjono, A. B. (2020). Traditional architecture of Kalang, Limasap (Ethnographic approach). International Journal of Scientific and Technology Research, 9(4), 2468-2475.

9. Idham, N. C. (2018). Javanese vernacular architecture and environmental synchronization based on the regional diversity of Joglo and Limasan. Frontiers of Architectural Research, 7(3), 317-333. https://doi.org/10.1016/j.foar.2018.06.006

10. Idham, N. C. (2021). Javanese islamic architecture: Adoption and adaptation of javanese and hindu-buddhist cultures in indonesia. Journal of Architecture and Urbanism, 45(1), 9-18. https://doi.org/10.3846/jau.2021.13709

11. Izziah, Meutia, E., Sahputra, Z., \& Irwansyah, M. (2021). Architecture in between: connecting between traditional Acehnese house and the current condition of modern Acehnese community. IOP Conference Series: Materials Science and Engineering, 1087(1), 012036. https://doi.org/10.1088/1757899X/1087/1/012036

12. Ju, S. R., Kim, D. Y., \& Santosa, R. B. (2018). Dualism in the Javanese house and transformation with focus on the houses of Kotagede, Yogyakarta. Journal of Asian Architecture and Building Engineering, 71-78. https://doi.org/10.3130/jaabe.17.71

13. Kameli, M., Fakhri, M., \& Mohammadi, M. (2016). EVALUATING GIRLS STUDENTS DORMITORIES WITH AN EMPHASIS ON COMFORT AND INTIMACY. Ciência $e$ Natura, $\quad 38(2), \quad 803$. https://doi.org/10.5902/2179460x21526

14. Mortada, H. (2003). Traditional Islamic Principles of Built Environment (1st ed.). Routledge.

15. Mustafa, M., Yudono, A., Wikantari, R., \& Harisah, A. (2016). Identifying Islamic Values in The Embodiment of Makassar Traditional Houses in Barombong Coastal. Proceedings of
Engineering and Technology Innovation, 2, 20-

22. https://doi.org/10.46604/PETI.2016.224

16. Naing, N., \& Hadi, K. (2020). Vernacular architecture of buginese: The concept of localwisdom in constructing buildings based on human anatomy. International Review for Spatial Planning and Sustainable Development, $\quad 8(3), \quad 1-15$. https://doi.org/10.14246/irspsda.8.3_1

17. Napitupulu, N., Aritonang, E., \& Silitonga, S. (2020). The Study about the Comparation between Batak Toba Traditional House in Huta Raja Samosir and Lumban Binanga Toba Samosir. IOP Conference Series: Earth and Environmental Science. https://doi.org/10.1088/1755$1315 / 452 / 1 / 012052$

18. Omer, S. (2010). Islam \& Housing. A.S. Noordeen.

19. Othman, Z. (2016). Privacy, modesty, hospitality and the design of Muslim homes in Australia. Queensland University of Technology.

20. Othman, Z., Aird, R., \& Buys, L. (2015). Privacy, modesty, hospitality, and the design of Muslim homes: A literature review. Frontiers of Architectural Research, 4(1), 12-23. https://doi.org/10.1016/j.foar.2014.12.001

21. Raka, A. A. G., \& Runa, I. W. (2018). Changes in Rural Settlement to Improve Ancient Villages Conservation Quality in BaliIndonesia. IOP Conference Series: Materials Science and Engineering, 434(1), 012224. https://doi.org/10.1088/1757899X/434/1/012224

22. Samra, B., \& Imbardi, I. (2020). Exploring Architectural Design of Istana Siak Sri Indrapura: The wisdom and environmental knowledges. IOP Conference Series: Earth and Environmental Science. https://doi.org/10.1088/17551315/469/1/012069

23. Santosa, R. B. (2019). OMAH Membaca Makna Rumah Jawa (R. B. Santosa (ed.); 1st ed.). RAW.

24. Sari, D. P., \& Chiou, Y. S. (2019). Transformation in architecture and spatial organization at Javanese house. Proceedings of the 2019 IEEE/ACM International Conference on Advances in Social Networks Analysis and Mining, ASONAM 2019, 570-577. 
https://doi.org/10.1145/3341161.3343684

25. Sari, I. kartika, Nuryanti, W., \& Ikaputra. (2019). The meaning of home: Privacy, modesty and hospitality in traditional Malay house, West Borneo, Indonesia. ISVS EJournal, 6(1), 22-31.

26. Siahaan, F. (2020). Identification of Application of Biological Architecture in the North Nias's Traditional House "Omo Hada" in Indonesia. IOP Conference Series: Earth and Environmental Science, 452, 012016. https://doi.org/10.1088/17551315/452/1/012016

27. Suharto, M. F., Kawet, R. S. S. I., \& Tumanduk, M. S. S. S. (2018). A Comparative Study of the Traditional Houses Kaili and Bugis-Makassar in Indonesia. IOP Conference Series: Materials Science and Engineering, 306(1), 012077. https://doi.org/10.1088/1757899X/306/1/012077

28. Suprapti. (2014). THE TRADITION OF LIVING OF MUSLIM COMMUNITY KUDUSKULON. Journal of Social Sciences, 10(2), 63-73. https://doi.org/10.3844/jssp.2014.63.73

29. Suprapti, A., Kim, S., Pandelaki, E. E., \& Firmandhani, S. W. (2018). A spatial dialogue of heritage village between kauman in Semarang and Seochon in Seoul toward preservation development. Journal of Architecture and Urbanism, 42(1), 16-23. https://doi.org/10.3846/jau.2018.1478

30. Suprapti, A., Kistanto, N. H., Pandelaki, E. E., \& Indrosaptono, D. (2017). Control of spatial protection in Kauman Semarang. Journal of Architecture and Urbanism, 41(4), 268-277. https://doi.org/10.3846/20297955.2017.14027 17

31. Wenyuan, Xin Janet (2020). Communal Space Design of High-Rise Apartments: A Literature Review. Journal of Design and Built Environement. JDBE-Vol 20(1) 35-49, April 2020.

32. Wiryomartono, B. (2014). Perspectives on Traditional Settlements and Communities. In Perspectives on Traditional Settlements and Communities. https://doi.org/10.1007/978981-4585-05-7

33. Zahrani, Z. K., \& Tabaeian, S. M. (2016). The Comparative Study of Privacy in Designing Qajar Dynasty Isfahan's Houses and Malaysia's Traditional Houses. Journal of Design and
Built Environment, $53-63$. https://doi.org/10.22452/jdbe.sp2016no1.6

34. Zulkifli A., Aminuddin Asrul;, Outdoor Space as Integral Component in Home making at Low-cost Housing in Bangsar, Kuala Lumpur. The Malaysia Architectural Journal, (MAJ), Vol 2, Issue 3, 2020. 